\title{
Influence of Soil Application of Micronized-Sulfur with Bentonite on Tomato Growth under Greenhouse Condition
}

\author{
Hayriye Yildiz Dasgan ${ }^{1}$, Nazmi Cemaloglu ${ }^{1}$, Yelderem Akhoundnejad ${ }^{1}$, Gunce Akkuzu Dogan ${ }^{2}$ and Mahmut \\ Bayram $^{3}$ \\ 1. Department of Horticulture, Agricultural Faculty, Cukurova University, Adana 01330, Turkey \\ 2. Balkan Sulfur, Fertilizer Limited Company, Istanbul 34956, Turkey \\ 3. GAP Agricultural Research Institute, Sanliurfa 63040, Turkey
}

\begin{abstract}
In this study, the influence of four different sulfur products applied to the soil on the organically grown greenhouse tomato was investigated. The sulfur treatments were: (1) micronized-sulfur with bentonite (MSB) alone ( $90 \%$ sulfur $+10 \%$ bentonite); (2) MSB + Fe (87\% sulfur $+10 \%$ bentonite $+3 \%$ Fe); (3) MSB + Zn (87\% sulfur $+10 \%$ bentonite $+3 \%$ Zn); (4) MSB + Fe + Zn (86\% sulfur $+10 \%$ bentonite $+2 \% \mathrm{Fe}+2 \% \mathrm{Zn}$ ) and (5) control without sulfur treatment. The effects of sulfur products on plant growth, total crop yield, some fruit quality parameters, Fe and $\mathrm{Zn}$ content of the leaves and soil, $\mathrm{pH}$ and electrical conductivity (EC) of soil, were investigated. Results showed that the effects of treatments on plant growth parameters and fruit quality properties were not significant. However, total fruit yield increased by about 14\%, 21\%, 15\% and 27\% in MSB, MSB + Fe, MSB + Zn and MSB + Fe + $\mathrm{Zn}$, respectively, as compared with control. Leaves Fe and Zn content were increased in some sampling times in related treatments. Soil Fe content was not changed by the treatments, however Zn content was significantly increased by the MSB + Zn and MSB + Fe $+\mathrm{Zn}$ applications. Soil $\mathrm{pH}$ was decreased by the all sulfur treatments in comparison to control; however the most important $\mathrm{pH}$ decrease was recorded as 0.28 units in MSB $+\mathrm{Fe}+\mathrm{Zn}$ treatment. Soil EC values of the all sulfur treatments were higher than the control.
\end{abstract}

Key words: Organic greenhouse, micronized-sulfur with bentonite, Solanum lycopersicum, soil pH, Fe, Zn.

\section{Introduction}

Intensive use of artificial fertilizers, hormones and pesticides impairs soil, water, air, food and living quality. In organic farming, in order to achieve environmentally friendly approaches instead of synthetic pesticides and fertilizers, organic and green manure, crop rotation for soil conservation, parasites and predators for plant protection are consciously preferred. In organic production, the main target is not the increasing amount of production; it is increasing of product quality. So the concept of organic farming has been used in many countries [1].

Corresponding author: Hayriye Yildiz Dasgan, professor, research fields: vegetables sciences, plant nutrition and abiotic stress, greenhouse soil and soilless cultures.
Sulfur is one of the materials that permitted for using in organic plant production in Turkey and all over the world in many years. There are four major reasons for the application of sulfur to the soil: reducing soil $\mathrm{pH}$, ensuring plant nutrient availability, advantages of sulfur to against soil pests and diseases, and source of sulfur as nutrient for the plant. Main expectation of sulfur products used in this study are reducing soil $\mathrm{pH}$ and increasing nutrient availability, therefore increasing crop yield and quality of organic tomato. Soil $\mathrm{pH}$ has important impact factors on the availability of nutrients, soil productivity and plant nutrition programs. The most important problems of high $\mathrm{pH}$ soil are unavailability of phosphor and trace elements, especially Fe and Zn [2]. 
In order to increase of $\mathrm{H}^{+}$concentration in soils, elemental sulfur, sulfuric acid or ammonium sulfate are applied to the soil. Among these, the sulfur is the most common one [2]. Using of sulfur products into the soil, besides lowering the $\mathrm{pH}$, it also plays a role in soil disinfection. It promotes resistance to soil born fungal and bacterial disease [3]. Therefore using of sulfur products has very important roles in organic greenhouse vegetable production.

Traditionally longstanding practice as a sulfur source was powder form. However, recently new generation product that is called the micronized-sulfur with bentonite (MSB) has become popular in the agricultural sector. In this new product, the liquid sulfur is absorbed by the bentonite clay, through solidification on rotoform granulation system and after drying, the final product is a granule that similar to lentil [4]. The bentonite increases its volume by factor of 3 to 5 when it comes into contact with water. When a MSB granule comes into contact with soil moisture, it breaks apart into fragments of micron-size particles, thus allowing swift and continuous solubilisation [4].

The particle size of any sulfur product is the most important factor for soil $\mathrm{pH}$ reducing. The smaller particle size increases the sulfur activity, because the oxidation of elemental sulfur to the $\mathrm{SO}_{4}{ }^{2-}$ will be faster. The smaller particle size also gives benefits to the Thiobacillus bacteria being larger infection area. In the MSB technology, the particle size is ultra small like microns that provides rapid and more acid formation [4]. The bentonite clay easily absorbs and storages plenty of water. Water availability, presence of the bacteria, small sulfur particle size and appropriate temperature allow easy oxidation [4]. Therefore, in weak soil, $\mathrm{pH}$ can be easily decreased in comparison to longer period of oxidation time for the conventional powder sulfur [5]. Nowadays, the conscious plant growers prefer the MSB product for soil application, due to its fast oxidation in the soil and more rapid $\mathrm{pH}$ reducing in comparison to powder form sulfur [5].

The objective of the article was to provide reducing soil $\mathrm{pH}$ for a yield increase in organic greenhouse tomato production by using MSB with the additives of Fe and Zn.

\section{Materials and Methods}

The experiment was carried out at plastic greenhouse with an area of $360 \mathrm{~m}^{2}$ in two consecutive years in Horticulture Department of Cukurova University. The study presented here is the second year experiment. Soil properties of the experimental greenhouse can be seen in Table 1, initial $\mathrm{pH}$ was 8.36 that was high, Fe concentration $3.24 \mathrm{ppm}$ was low and Zn $1.62 \mathrm{ppm}$ was critical for the greenhouse tomato crop. Alsancak $F_{1}$ tomato cultivar is used as plant material. Seeds were sown into 2:1 peat:perlite containers on January 15, 2014 in glasshouse. When five true leaves emerged, tomato seedlings were transplanted in plastic greenhouse on February 20, 2014. The following treatments were used in the experiment:

(1) control without sulfur treatment;

(2) MBS alone ( $90 \%$ sulfur $+10 \%$ bentonite);

(3) $\mathrm{MBS}+\mathrm{Fe}(87 \%$ sulfur $+10 \%$ bentonite $+3 \%$ $\mathrm{Fe})$;

(4) MBS + Zn (87\% sulfur $+10 \%$ bentonite $+3 \%$ $\mathrm{Zn})$;

(5) $\mathrm{MBS}+\mathrm{Fe}+\mathrm{Zn}(86 \%$ sulfur $+10 \%$ bentonite + $2 \% \mathrm{Fe}+2 \% \mathrm{Zn})$.

The MSB treatments applied to the greenhouse soil with $500 \mathrm{~kg} / \mathrm{ha}$ dose at five months before the transplanting. Decomposed farmyard manure with the dose of 2,500 kg/ha was equally applied at all treatment parcels before planting. Initial soil analysis was performed (Table 1). Plant nutrition protocols were the same for each treatment and obtained from the organic fertilizers: $180 \mathrm{~kg} / \mathrm{ha} \mathrm{N}, 45 \mathrm{~kg} / \mathrm{ha} \mathrm{P}_{2} \mathrm{O}_{5}$, $400 \mathrm{~kg} / \mathrm{ha} \mathrm{K}_{2} \mathrm{O}$ and $205 \mathrm{~kg} / \mathrm{ha} \mathrm{MgO}$. The experiment was arranged in a completely randomized block design with five treatments and four replications. Each 
Table 1 Initial some properties of soil taken from $0-30 \mathrm{~cm}$ depth.

\begin{tabular}{lll}
\hline Soil properties & Methods & Results \\
\hline $\mathrm{pH}$ & 1:2.5 soil:water (v:v) & 8.36 \\
Calcareous (\%) & Calcimetric & 24.60 \\
Salt (\%) & 1:2.5 soil:water (v:v) & 0.093 \\
Organic matter (\%) & Walkley Black & 0.90 \\
Available Fe (ppm) & DTPA-ICP & 3.24 \\
Available Zn (ppm) & DTPA-ICP & 1.62 \\
\hline DTPA-ICP: diethylenetriaminepentaacetic & acid-inductively \\
coupled plasma. & &
\end{tabular}

replication included 16 plants. The tomato seedlings were planted with double rows and plant density of 33,333 plants/ha. The spacing between double rows was $100 \mathrm{~cm}$ and $50 \mathrm{~cm}$, and the spacing between plants was $40 \mathrm{~cm}$, respectively. In order to see the effect of treatments, during the cultivation period, soil samples taken from 0-30 cm depth three times on March 28, 2014, April 25, 2014 and May 30, 2014, respectively, for the analysis of soil $\mathrm{pH}$, electrical conductivity (EC) and micronutrient contents of Fe and Zn.

Stem diameter and number of leaves were recorded during the experiment three times in the same dates of soil sampling. Fruit harvests were performed weekly. Fruit harvest began on May 16, 2014, continued until the date of July 10, 2014 and the totally nine harvests were made. At the middle of the harvest period, 10 fruits from each replicate were selected randomly for the fruit pomological and some quality properties analysis.

Data were statistically analyzed using analysis of variance (ANOVA) and the means were separated by least significant difference (LSD) $(P<0.05)$ using JUMP software.

\section{Results and Discussion}

The MSB treatments affected soil and yield at different grades. $\mathrm{pH}$ was decreased by 0.28 unit and yield was increased by $27 \%$.

\subsection{Plant Growth Parameters}

Plant height, leaf number and stem diameter on different three measuring dates were not significantly different in the MSB treated plants (Tables 2-4). Although these vegetative parameters were not significant, maybe photosynthesis, leaf area or plant dry weights were higher in MSB treated plants, because sulfur treatment caused the yield increases (Table 5). It is reported by Yaras and Dasgan [5] that when comparing conventional greenhouse tomato cultivation by $150 \mathrm{~kg} / \mathrm{ha}$ MSB, 2,000 kg/ha leonardit, plant height measurements was the highest with $156.21 \mathrm{~cm} /$ plant in leonardit treatment, the lowest in control plants with $138.14 \mathrm{~cm} /$ plant and middle in MSB treatment with $145.02 \mathrm{~cm} /$ plant. The leaf number in the same study was the highest with 26.18 leaves/plant in leonardit, the lowest in control plants with 24.66 leaves and middle in MSB with 25.73 leaves.

\subsection{Yield Production}

The effects of the MSB treatments on tomato yield

Table 2 Effect of MSB treatments on plant height $(\mathrm{cm})$ in organically grown greenhouse tomato plants.

\begin{tabular}{llll}
\hline \multirow{2}{*}{ Treatments } & \multicolumn{3}{c}{ Plant height $(\mathrm{cm})$} \\
\cline { 2 - 4 } & March 28, & April 25, & May 30, \\
& 2014 & 2014 & 2014 \\
\hline Control & 56.50 & 116.63 & 190.23 \\
MSB & 57.80 & 115.03 & 194.05 \\
MSB + Fe & 57.20 & 113.93 & 193.93 \\
MSB + Zn & 55.93 & 112.70 & 192.75 \\
MSB + Fe + Zn & 57.53 & 115.03 & 194.35 \\
\hline LSD $_{0.05}$ & ns & ns & ns \\
\hline
\end{tabular}

ns: not significant.

Table 3 Effect of MSB treatments on the number of leaves (number/plant) in organically grown greenhouse tomato plants.

\begin{tabular}{llll}
\hline \multirow{2}{*}{ Treatments } & \multicolumn{3}{c}{ Number of leaves/plant } \\
\cline { 2 - 4 } & March 28, & April 25, & May 30, \\
& 2014 & 2014 & 2014 \\
\hline Control & 13.45 & 19.93 & 28.50 \\
MSB & 13.03 & 20.65 & 29.55 \\
MSB + Fe & 13.15 & 19.73 & 30.55 \\
MSB + Zn & 13.47 & 20.10 & 29.58 \\
MSB + Fe + Zn & 13.10 & 19.80 & 30.80 \\
\hline LSD $_{0.05}$ & ns & ns & ns \\
\hline
\end{tabular}

ns: not significant. 

Tomato Growth under Greenhouse Condition

Table 4 Effect of MSB treatments on stem diameter (mm) in organically grown greenhouse tomato plants.

\begin{tabular}{llll}
\hline \multirow{2}{*}{ Treatments } & \multicolumn{3}{c}{ Stem diameter (mm) } \\
\cline { 2 - 4 } & March 28, & April 25, & May 30, \\
& 2014 & 2014 & 2014 \\
\hline Control & 12.09 & 14.24 & 16.49 \\
MSB & 12.39 & 14.05 & 16.20 \\
MSB + Fe & 12.17 & 14.63 & 16.89 \\
MSB + Zn & 12.29 & 14.52 & 16.84 \\
MSB + Fe + Zn & 12.19 & 14.14 & 17.08 \\
\hline LSD $_{0.05}$ & ns & ns & ns \\
\hline
\end{tabular}

ns: not significant.

Table 5 Effect of MSB treatments on tomato fruit yield in organically grown greenhouse tomato plants.

\begin{tabular}{ll}
\hline Treatments & Tomato fruit yield $\left(\mathrm{kg} / \mathrm{m}^{2}\right)$ \\
\hline Control & $15.30^{\mathrm{c}}$ \\
$\mathrm{MSB}$ & $17.39^{\mathrm{b}}$ \\
$\mathrm{MSB}+\mathrm{Fe}$ & $18.46^{\mathrm{ab}}$ \\
$\mathrm{MSB}+\mathrm{Zn}$ & $17.58^{\mathrm{b}}$ \\
$\mathrm{MSB}+\mathrm{Fe}+\mathrm{Zn}$ & $19.37^{\mathrm{a}}$ \\
\hline $\mathrm{LSD}_{0.05}$ & 1.32 \\
\hline
\end{tabular}

${ }^{a-c}$ The same letters present the non-significant difference at $95 \%$ confidential level.

were statistically significant (Table 5). The highest yield with $19.37 \mathrm{~kg} / \mathrm{m}^{2}$ was obtained from the MSB + $\mathrm{Fe}+\mathrm{Zn}$ treatment. The application of MSB + Fe took the second place with $18.46 \mathrm{~kg} / \mathrm{m}^{2}$. The treatments
MSB alone and $\mathrm{Zn}$ added sulfur products were very close to each other with $17.39 \mathrm{~kg} / \mathrm{m}^{2}$ and $17.58 \mathrm{~kg} / \mathrm{m}^{2}$, respectively. The lowest yield of organically grown tomato in the experiment was $15.30 \mathrm{~kg} / \mathrm{m}^{2}$ from the control. When the MSB products applied to greenhouse soil, two consecutive years led to increase of organic tomato yield by about 13.7\%, 20.7\%, $14.9 \%$ and $26.6 \%$ in the treatments of MSB, MSB + $\mathrm{Fe}, \mathrm{MSB}+\mathrm{Zn}, \mathrm{MSB}+\mathrm{Fe}+\mathrm{Zn}$, respectively, as compared with control (Fig. 1).

In the organically grown greenhouse tomato production, use of the MSB and its derivatives with $\mathrm{Fe}$ and $\mathrm{Zn}$ increased the fruit yield between 14\% and $26 \%$. Soil $\mathrm{pH}$ was reduced 0.28 units in comparison to the beginning $\mathrm{pH}$. In greenhouse tomato cultivation, use of the MSB products, beside the $\mathrm{pH}$-reducing effects and increasing nutrient availability by increasing soil EC, could also have some possible benefits on soil disinfection against soil born diseases (no data shown, but there was observation).

Tomato yield reported from the conventional greenhouse tomato production with $150 \mathrm{~kg} / \mathrm{ha}$ MSB and 2,000 kg/ha leonardite were increased $23 \%$ and $18 \%$, respectively [5]. Some organic and inorganic

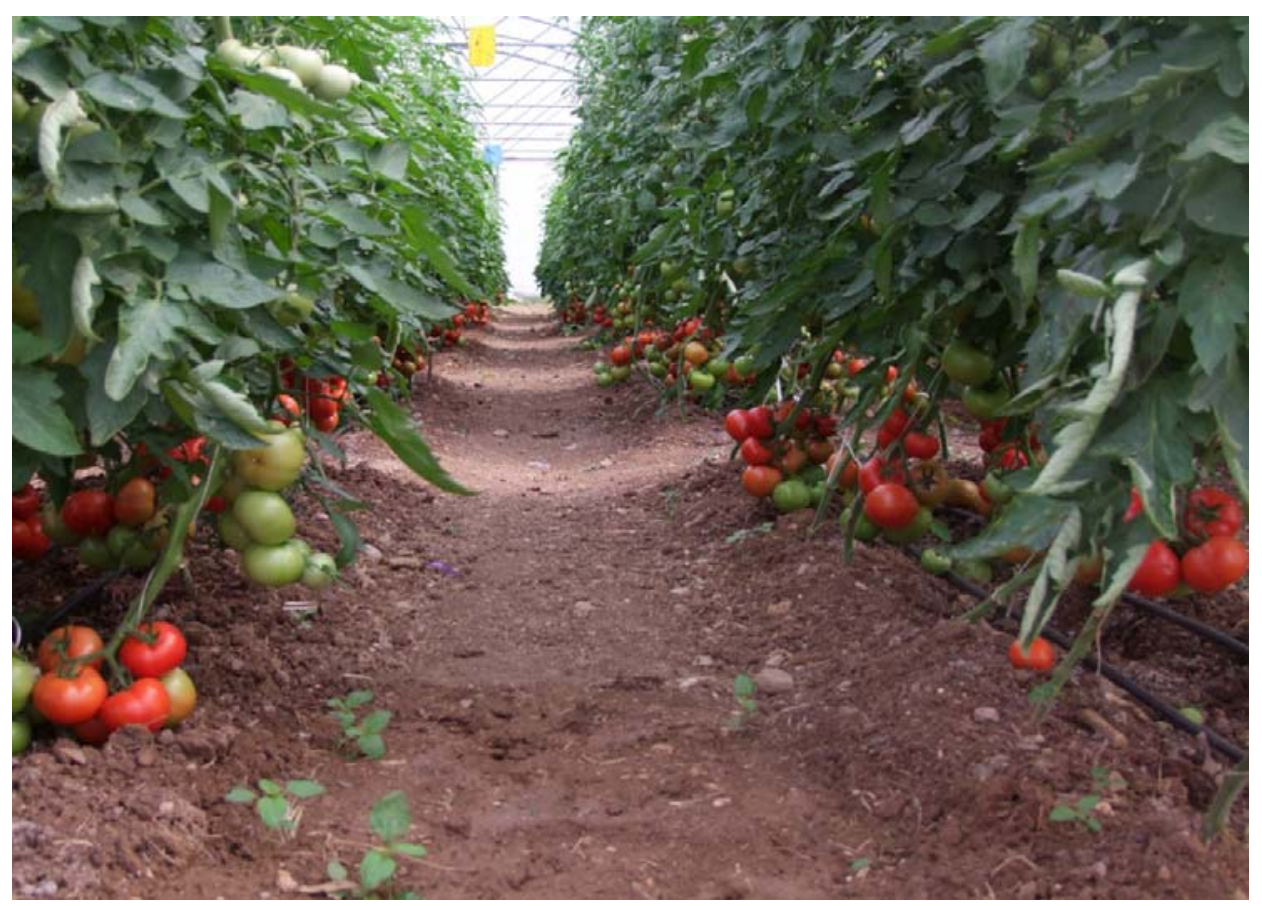

Fig. 1 Tomato fruits during harvest stage from the experimental organic greenhouse. 

Tomato Growth under Greenhouse Condition

Table 6 Effect of MSB treatments on fruit physical quality characteristics in organically grown greenhouse tomato plants.

\begin{tabular}{lllllll}
\hline Applications & $\begin{array}{l}\text { Fruit weight } \\
(\mathrm{g})\end{array}$ & $\begin{array}{l}\text { Fruit length } \\
(\mathrm{mm})\end{array}$ & $\begin{array}{l}\text { Fruit diameter } \\
(\mathrm{mm})\end{array}$ & $\begin{array}{l}\text { Fruit firmness } \\
\left(\mathrm{kg} / \mathrm{cm}^{2}\right)\end{array}$ & $\begin{array}{l}\text { Flesh thickness } \\
(\mathrm{mm})\end{array}$ & $\begin{array}{l}\text { Fruit volume } \\
\left(\mathrm{cm}^{3}\right)\end{array}$ \\
\hline Control & 219 & 60 & 75 & 1.3 & 9.8 & 176 \\
MSB & 202 & 60 & 73 & 1.2 & 8.9 & 162 \\
$\mathrm{MSB}+\mathrm{Fe}$ & 197 & 58 & 74 & 1.3 & 9.3 & 156 \\
$\mathrm{MSB}+\mathrm{Zn}$ & 208 & 60 & 75 & 1.2 & 9.9 & 167 \\
MSB + Fe + Zn & 220 & 60 & 76 & 1.1 & 9.1 & 179 \\
\hline LSD $_{0.05}$ & $\mathrm{~ns}$ & $\mathrm{~ns}$ & $\mathrm{~ns}$ & $\mathrm{~ns}$ & $\mathrm{~ns}$ & $\mathrm{~ns}$ \\
\hline
\end{tabular}

ns: not significant.

Table 7 Effect of MSB treatments on fruit juice quality characteristics in organically grown greenhouse tomato plants.

\begin{tabular}{lllll}
\hline Applications & TSS (\%) & Acidity (\%) & $\mathrm{pH}$ & $\mathrm{EC} \mathrm{(dS/m)}$ \\
\hline Control & 3.83 & 0.30 & 4.77 & 5.30 \\
MSB & 3.79 & 0.29 & 4.67 & 5.20 \\
$\mathrm{MSB}+\mathrm{Fe}$ & 4.03 & 0.31 & 4.60 & 5.50 \\
$\mathrm{MSB}+\mathrm{Zn}$ & 3.73 & 0.27 & 4.70 & 5.30 \\
$\mathrm{MSB}+\mathrm{Fe}+\mathrm{Zn}$ & 3.98 & 0.30 & 4.68 & 5.30 \\
\hline $\mathrm{LSD}_{0.05}$ & $\mathrm{~ns}$ & $\mathrm{~ns}$ & $\mathrm{~ns}$ & $\mathrm{~ns}$ \\
\hline
\end{tabular}

TSS: total soluble solids; ns: not significant.

Table 8 Effect of MSB treatments on leaf Fe concentration in organically grown greenhouse tomato plants.

\begin{tabular}{llll}
\hline \multirow{2}{*}{ Applications } & \multicolumn{3}{c}{ Leaf Fe concentration (ppm) } \\
\cline { 2 - 4 } & March 28, & April 25, & May 30, \\
& 2014 & 2014 & 2014 \\
\hline Control & $168^{\mathrm{a}}$ & 100 & 135 \\
MSB & $128^{\mathrm{b}}$ & 126 & 173 \\
MSB + Fe & $131^{\mathrm{b}}$ & 118 & 161 \\
MSB + Zn & $143^{\mathrm{ab}}$ & 124 & 141 \\
MSB + Fe + Zn & $126^{\mathrm{b}}$ & 122 & 155 \\
\hline LSD $_{0.05}$ & 26.30 & $\mathrm{~ns}$ & $\mathrm{~ns}$ \\
\hline
\end{tabular}

a, $\mathrm{b}$ The same letters present the non-significant difference at 95\% confidential level; ns: not significant.

fertilizer treatments on yield and quality of conventionally grown cherry tomato were also reported by Demirtas et al. [6] and the highest yield was obtained from the combination of inorganic and organic fertilizer in 1:1 ratio. Wang et al. [7] examinated the effects of organic and inorganic fertilizers with additional $35 \mathrm{~L} / \mathrm{ha}$ humic acid on grape yield. Organic fertilizer with combination humic acid provided the highest yield in comparison to the other treatment, and increased sugar content of fruit. For potato production, among the sources of MSB and gypsum, MSB was found to be best source of S because of high concentration, slow release and minimum leaching loss $[8,9]$.

\subsection{Fruit Quality}

In the middle of the harvest season, 10 fruits from each replication were used for some physical and chemical analyses of the fruits. The MSB treatments in this experiment were not significantly different in the fruit size and juice features (Tables 6 and 7). The reason of increasing total fruit yield in MSB treatments (Table 5) could be due to increasing the number of fruit or fruit set on a plant. Because there were no any significant effects of the MSB treatments on fruit size characteristics as weight, width and diameter. In the conventional greenhouse tomato production with $150 \mathrm{~kg} / \mathrm{ha}$ MSB and 2,000 kg/ha leonardite informed that the treatments did not make any significant difference on fruit characteristics [5].

\subsection{Micronutrient Content of Leaves}

Iron $(\mathrm{Fe})$ concentration in leaves of the MSB treatments have been increased by the time (Table 8). In the first leave analysis, the control plants showed the higher Fe content, however in the 3rd analyses, the MBS treatments increased $\mathrm{Fe}$ contents. These increases could be due to $\mathrm{pH}$ reduction effects of MSB treatments on experimental soils, and Fe availability could be increased for the plants. There were no any remarkable difference among the MSB treatments for the leaf Fe concentrations (Table 8). In the report about the conventional greenhouse tomato production with $150 \mathrm{~kg} / \mathrm{ha}$ MSB and 2,000 kg/ha leonardite [5], it 
was informed that leaves Fe contents were $62.31 \mathrm{ppm}$ and $70.76 \mathrm{ppm}$ in MSB and leonardit treatments, respectively. In the case of adequate Fe nutrition in tomato plants, leaf Fe concentration was reported to be between $50 \mathrm{ppm}$ and $200 \mathrm{ppm}$ [10].

The differences of the MSB treatments on leaf Zn concentrations were not noticeable as in the case of Fe (Table 9). Leaf $\mathrm{Zn}$ contents in the treatments were similar. In the conventional greenhouse tomato production [5] with $150 \mathrm{~kg} / \mathrm{ha}$ MSB and 2,000 kg/ha leonardite, leaf $\mathrm{Zn}$ concentrations were reported $140.91 \mathrm{ppm}$ and $82.40 \mathrm{ppm}$ in MSB and leonardit treatments, respectively. In the case of adequate $\mathrm{Zn}$ nutrition in tomato plants, leaf Zn concentration was reported to be between $20 \mathrm{ppm}$ and $250 \mathrm{ppm}$ [10].

\subsection{Soil $p H$ and $E C$}

At the completion of the experiment, approximately 10 months after the soil application of the treatments, $\mathrm{pH}$ reduction of MSB treatments were between 0.10 and 0.28 units (Table 10). While the control $\mathrm{pH}$ was

Table 9 Effect of MSB treatments on leaf Zn concentration (ppm) in organically grown greenhouse tomato plants.

\begin{tabular}{llll}
\hline \multirow{2}{*}{ Applications } & \multicolumn{3}{c}{ Leaf Zn concentration (ppm) } \\
\cline { 2 - 4 } & March 28, & April 25, & May 30, \\
& 2014 & 2014 & 2014 \\
\hline Control & 204 & 88 & 157 \\
MSB & 219 & 69 & 180 \\
MSB + Fe & 220 & 56 & 146 \\
MSB + Zn & 230 & 66 & 146 \\
MSB + Fe + Zn & 225 & 61 & 162 \\
\hline LSD & ns & ns & ns
\end{tabular}

Table 10 Effect of MSB applications on soil pH and EC values organically grown greenhouse tomato plants.

\begin{tabular}{lll}
\hline Treatments & $\mathrm{pH}$ & $\mathrm{EC}(\mathrm{dS} / \mathrm{m})$ \\
\hline Control & $8.36^{\mathrm{a}}$ & $0.48^{\mathrm{c}}$ \\
$\mathrm{MSB}$ & $8.25^{\mathrm{ab}}$ & $0.60^{\mathrm{bc}}$ \\
$\mathrm{MSB}+\mathrm{Fe}$ & $8.19^{\mathrm{ab}}$ & $0.64^{\mathrm{bc}}$ \\
$\mathrm{MSB}+\mathrm{Zn}$ & $8.22^{\mathrm{ab}}$ & $0.71^{\mathrm{b}}$ \\
$\mathrm{MSB}+\mathrm{Fe}+\mathrm{Zn}$ & $8.08^{\mathrm{b}}$ & $1.14^{\mathrm{a}}$ \\
\hline $\mathrm{LSD}_{0.05}$ & 0.15 & 0.16 \\
\hline
\end{tabular}

a-c The same letters present the non-significant difference at 95\% confidential level.
Table 11 Effect of MSB applications on soil Fe and Zn concentrations (ppm) in organically grown greenhouse tomato plants.

\begin{tabular}{lll}
\hline Treatments & $\begin{array}{l}\text { Soil Fe } \\
\text { concentration } \\
(\mathrm{ppm})\end{array}$ & $\begin{array}{l}\text { Soil Zn } \\
\text { concentration } \\
(\mathrm{ppm})\end{array}$ \\
\hline Control & 2.96 & $2.92^{\mathrm{c}}$ \\
$\mathrm{MSB}$ & 2.97 & $2.62^{\mathrm{c}}$ \\
$\mathrm{MSB}+\mathrm{Fe}$ & 2.72 & $2.22^{\mathrm{c}}$ \\
$\mathrm{MSB}+\mathrm{Zn}$ & 2.82 & $12.17^{\mathrm{b}}$ \\
$\mathrm{MSB}+\mathrm{Fe}+\mathrm{Zn}$ & 2.96 & $18.59^{\mathrm{a}}$ \\
\hline $\mathrm{LSD}_{0.05}$ & $\mathrm{~ns}$ & 2.52
\end{tabular}

a-c The same letters present the non-significant difference at 95\% confidential level; ns: non significant.

8.36, remarkable reduction from the $\mathrm{MSB}+\mathrm{Fe}+\mathrm{Zn}$ treatment was 0.28 units and $\mathrm{pH}$ was 8.08. The minimum $\mathrm{pH}$ reduction was 0.10 units from the MSB alone and $\mathrm{pH}$ was 8.25 . In studies of the conventional greenhouse tomato production with $150 \mathrm{~kg} / \mathrm{ha}$ MSB and 2,000 kg/ha leonardite [5], MSB and leanardite treatments reduced the soil $\mathrm{pH}$ by 0.51 and 0.45 units, respectively, during approximately 10 months.

The EC values of the experimental soils at the end of the production period were increased by the MSB treatments. Among the EC values, the lowest one was the control treatment $(0.48 \mathrm{dS} / \mathrm{m})$, as shown in Table 10. The highest $\mathrm{EC}$ was from the $\mathrm{MSB}+\mathrm{Fe}+\mathrm{Zn}$ by $1.14 \mathrm{dS} / \mathrm{m}$. The EC values of the MSB + Zn, MSB + Fe and MSB alone were $0.71,0.64$ and $0.60 \mathrm{dS} / \mathrm{m}$, respectively.

\subsection{Soil Fe and Zn Concentrations}

At the end of the experiment, $\mathrm{Fe}$ and $\mathrm{Zn}$ concentrations of the experimental soils were measured and there was no any significant difference for $\mathrm{Fe}$ concentrations of the treatments. However, MSB $+\mathrm{Zn}$ treatments showed the higher $\mathrm{Zn}$ contents. MSB + Fe + Zn and MSB + Zn had 18.59 ppm and 12.17 ppm of soil Zn concentrations, respectively (Table 11). Tomato plants generally require more $\mathrm{Fe}$ than $\mathrm{Zn}$; for this reason, all Fe added to the soil with MSB applications could be consumed by the plants, and maybe in future during the manufacturing, it could be required to add more Fe into the MSB products [4]. 


\section{Conclusions}

From the conclusion of this study in greenhouse tomato production during soil tillage, the MSB products, preferably $\mathrm{Fe}$ and $\mathrm{Zn}$ added ones, can be applied to the soil and this soil application will increase yield due to $\mathrm{pH}$ reducing and nutrient availability for the plants. In future studies, the content of $\mathrm{Zn}$ and $\mathrm{Fe}$ as additives can be investigated with more detail, maybe Fe content needs to increase.

\section{Acknowledgments}

This study was supported by the Republic of Turkey Ministry of Food Agriculture and Livestock, by the project TAGEM/12/AR-GE/29 and Cukurova University by the project ZF2013YL28. The authors want to thank to the Balkan Sulfur Limited Company for providing the MSB products.

\section{References}

[1] Rehber, E., and Turhan, S. 2002. "Prospects and Challenges for Developing Countries in Trade and Production of Organic Food and Fibers: The Case of Turkey.” British Food Journal 104 (3-5): 371-90.

[2] The Sulphur Institute. 2016. "Sulpur-An Advantaged Element.” Accessed November, 2016. http://www.sulphurinstitute.org/.

[3] Bloem, E., Haneklaus, S., and Schnug, E. 2005.
"Significance of Sulfur Compounds in the Protection of Plants Against Pests and Diseases." Journal of Plant Nutrition 28 (5): 763-84.

[4] Akkuzu, G., Kamisli, M., Dasgan, H. Y., Turemis, N., and Uncu, E. 2016. Efficiencies of Micronized Bentonite Sulfur and Its Derivatives with $\mathrm{Fe}$ and $\mathrm{Zn}$ on Tomato, Strawberry and Wheat. TAGEM12/AR-GE/29, Final Project Report, TAGEM, Ankara.

[5] Yaras, K., and Dasgan, H. Y. 2012. "Effects of Soil-Applied Micronized-Sulphur with Bentonite and Organic Matter on Soil pH, Tomato Plant Growth, Yield and Fruit Quality under Greenhouse Conditions.” Tarm Bilimleri Araştırma Dergisi 5 (1): 175-80.

[6] Demirtas, E. I., Ari, N., Arpacioglu, A. E., Ozkan, C. F., and Aslan, H. 2007. "The Effects of Using Mushroom West on Soil Properties of Greenhouse Tomato and Crop Yield.” In Proceeding of the 5th National Horticultural Congress, 220-3.

[7] Wang, C. D., Chan, H. T., and Lay, C. L. 1991. "Effect of Organic Manures on the Yield and Quality of Grapes.” Bulletin of Taichung District Agricultural Improvement Station 32: 41-8.

[8] Jena, D., and Kabi, S. 2012. "Effect of Gromor Sulphur Bentonite Sulphur Pastilles on Yield and Nutrient Uptake by Hybrid Rice-Potato-Green Gram Cropping System in an Inceptisol.” Int. Res. J. Agri. Sci. Soil Sci. 2 (5): 179-87.

[9] Nayak, K. V., and Vijayrao, P. 2012. "Role of Bentonite Sulphur in Improving Yield and Quality of Crops.” Indian Journal of Fertilizers 8 (4): 84-92.

[10] Winsor, G., and Adams, P. 1987. Glasshouse Crops. Vol. 3. London: Her Majesty's Stationery Office (HMSO), 109-35. 